\title{
La vacuna antineumocócica redujo la incidencia de otitis media aguda de algunos serotipos
}

Efficacy of pneumococcal conjugate vaccine against acute otitis media. Juhani E,Terhi K,Arto P y col. N Engl J Med .2001 Feb 8;344:403409

\section{Objetivo}

Evaluar la eficacia y seguridad de la vacuna antineumocócica conjugada en la disminución de la incidencia de otitis media aguda (OMA), por S. pneumoniae, en niños menores de dos años.

\section{Diseño}

Ensayo clínico aleatorizado y doble ciego.

\section{Lugar}

Tres comunidades de Finlandia.

\section{Pacientes}

Niños recién nacidos, en la primer consulta pediátrica $(n=1662)$.

\section{Intervención}

Se aleatorizaron dos grupos de 831 niños en cada uno a recibir: 1) Vacuna antineumocócica (serotipos $4,6 \mathrm{~B}, 9 \mathrm{~V}, 14,18 \mathrm{C}, 19 \mathrm{~F}$ y $23 \mathrm{~F}$, conjugada con proteína transportadora CRM197,análoga de toxina diftérica atóxica, elaborada por Wyeth Lederle). 2) Vacuna para hepatitis B (elaborada por Merck Sharp \& Dohme). Esquema de administración: 4 dosis IM en el muslo (a los 2, 4, 6 y 12 meses de edad).

\section{Medición de resultados principales}

Se realizó punción timpánica, para cultivo bacteriológico, a todos los niños que presentaron criterios clínicos diagnósticos. La serotipificación del S. pneumoniae se realizó por contrainmunoelectroforesis y aglutinación del látex. La concentración de anticuerpos séricos $\lg G$, contra los 7 serotipos, fue medida por Enzimo Inmuno Ensayo en 115 niños a los 7 y 13 meses de edad.

\section{Resultados principales}

El 95,1\% de los niños completó el seguimiento hasta los 2 años de edad. El número de episodios de OMA, por serotipos contenidos en la vacuna, se redujo un 54\% (IC95\% 41 a $64 \%$ ). Además, se observó una reducción del 51\% (IC95\% 27-67\%) en los episodios por serotipos con reacción cruzada con los incluidos en la vacuna $(6 \mathrm{~A}, 9 \mathrm{~N}, 18 \mathrm{~B}, 19 \mathrm{~A}, 23 \mathrm{~A})$. Hubo una tendencia de incremento de $33 \%$ (IC95\% -1 a 80\%) en episodios por otros serotipos no incluidos en la vacuna (125 en vacunados vs. 95 en controles). La eficacia de la vacuna fue del 6\% (IC95\% -4 a 16\%) para la OMA de cualquier etiología. Hubo una tendencia a la disminución de los episodios recurrentes ( $\geq 3$ episodios en 6 meses ó $\geq 4$ en 1 año) del $9 \%$ (IC95\% -12 a 27\%). La concentración de anticuerpos, medida en la cohorte de seguimiento serológico, fue mayor en el primer grupo que en el control, con un incremento de los niveles de anticuerpos de 50 a $350 \%$ luego de las cuatro dosis. Sin embargo, el nivel de anticuerpos no tuvo correlación con el efecto protector.

En el grupo que recibió vacuna antineumocóccica solo fue más frecuente la fiebre luego de la tercera dosis, con respecto al grupo control ( $2 \%$ vs $0,5 \% . p=0.01)$. En el primer grupo hubo una bacteriemia por serotipo $7 \mathrm{y}$ en el grupo control dos meningitis por serotipos $23 \mathrm{~F}$ y 15 y una bacteriemia por serotipo $19 \mathrm{~F}$.

\section{Conclusiones}

La vacuna antineumocóccica conjugada es segura y efectiva en niños menores de dos años para la prevención de la OMA causada por los serotipos incluidos en la vacuna y por los que tienen reacción cruzada con éstos.

\section{Comentario}

La vacuna antineumocóccica contra 23 serotipos no es inmunogénica en niños menores de dos años, en cambio la heptavalente conjugada es inmunogénica en este grupo etario y cubre más del $85 \%$ de los serotipos de $\mathrm{S}$. pneumoniae que provocan enfermedad invasiva por neumococo en EE.UU.

El $50-60 \%$ de las OMA son bacterianas y de éstas $20-40 \%$ son causadas por el S. pneumoniae, además, en EEUU, luego de la introducción de la vacuna contra el H. Influenzae, el S. pneumoniae pasó a ser la causa más frecuente de meningitis en niños de esa edad.

Un estudio realizado en California demostró que esta vacuna tuvo una eficacia de casi el $100 \%$ contra la infección neumocócica invasiva, y reducción del 7\% en episodios de OMA de cualquier etiología1.

En el presente estudio se observó una reducción del número de episodios de OMA causadas por serotipos contenidos en la vacuna o por los que tenían reacción cruzada con éstos; tendencia a disminución del $6 \%$ de OMA de cualquier etiología (IC 95\% - 4 a $16 \%$ ), lo que podría indicar incremento en el número de episodios de hasta $4 \%$. Otro hallazgo fue el aumento de OMA por serotipos distintos a los incluidos en la vacuna; esto último también fue reportado por otros auttores; que además describieron cambios en los serotipos de S. pneumoniae que colonizaban la nasofaringe de los pacientes vacunados. 2

Según estudios realizados en el Hospital de Niños de Buenos Aires, "Dr. Ricardo Gutiérrez", el $40 \%$ de las OMA son causadas por este germen y más del $40 \%$ presentan algún grado de resistencia a la penicilina.

Los serotipos más frecuentes, aislados de enfermedad invasiva, fueron el 14, 1,5, 6A/B, 7F,19F y 23F; por lo que esta vacuna cubriría el $53 \%$ de los serotipos que provocan enfermedad invasiva y el $90 \%$ de las cepas resistentes. 3

Una consideración importante es el costo de la vacuna: aproximadamente $87 \$$ por dosis.

Hasta el momento, esta vacuna no está incluida en el plan nacional de vacunación obligatoria; tampoco existe una recomendación por consenso, en nuestro medio, para su uso generalizado; sin embargo su prescripción es una herramienta potencialmente útil que deberá ser evaluada para cada caso en particular y de acuerdo al criterio clínico del médico tratante.

\section{Dra. Estela Salazar Schicchi [ Sección Infectología. Hospital Italiano de Buenos Aires ]}

Referencias

1. Black S,Shinefield H,Fireman B y col.Efficacy,safety and inmunogenicity of heptavalent pneumococcal conjugate vaccine in children.Pediatr Infect Dis J.2000;19:187-95.

2.Mbelle N, Huebner R, Wasas A y col.Inmunogenicity and impact on nasopharyngeal carriage of a nonavalent pneumococcal conjugate vaccine. The Journal of Infectious Diseases. 1999; 180:$1171-6$. 